\title{
THE REFORM OF PUBLIC ADMINISTRATION IN KOSOVO
}

\author{
MSc. Milot KRASNIQI (iD $1 *$ \\ MSc. Laura TAHIRI (iD) 2 \\ Azem KOLLONI, PhD. C (iD 3
}

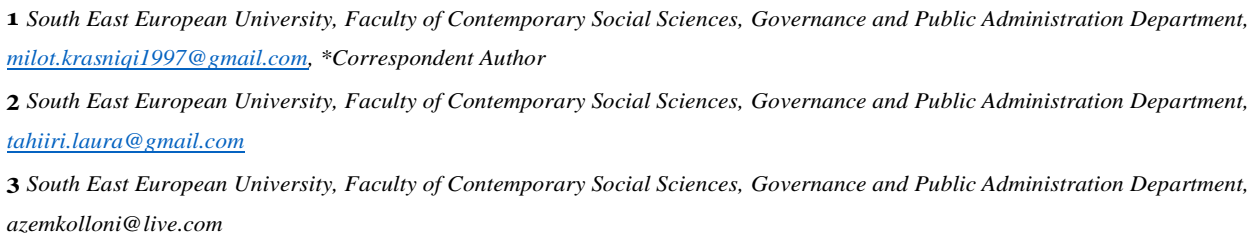

\section{Article history:}

Accepted 21 July 2020

Available online 31 August 2020

\section{Keywords:}

Reform,

Public Administration,

Electronic Government.

\begin{abstract}
A b s t r a c t
The reform of Public Administration in Kosovo is an essential part of the State-Building process. By the administrative reform, the Government aims to modernize the Public Administration, to strengthen its capacities and to make it more efficient and accountable. The post-conflict period in Kosovo from 1999 when the building of the new Public Administration in Kosovo began until the beginning of the administrative reform is a relatively difficult period for Kosovo. The reform of the Public Administration in Kosovo is manifested in two ways: first, in relation to its own development structure and, secondly, in relation to the functions it performs, the effects which are realized and the services provided to Institutions and citizens. The implementation of E-Government in Public Administration in Kosovo enables all efficient categories of Government services, at any time and from any distance, in order to meet daily needs of citizens. E-Government modernizes the administration and enables the creation of an efficient and accountable management at all levels of administration. Through the provision of electronic services to citizens, Kosova will be part of Europe.
\end{abstract}

\section{Introduction}

The State is functional and efficient only with a developed, professional and accountable Public Administration. In modern times, when the use of technology, especially information, has become a necessary part of life and work, the changes created have prompted new developments and reforms in many areas, including public administration (Waldo, 1972). Public Administration has become an instrument of central Government to deal with general social problems. The term Public Administration means "the implementation of Government policies (Random House Unabridged Dictionary) and an Academic discipline that studies this implementation and prepares civil servants for work." Some of the various definitions that have been offered regarding the term Public Administration refer to meanings such as: "Management of Public programs", (Robert \& Denhardt, 2009)" translation of politics into the reality that citizens experience every day", (Donald \& Fessler, 2009) " the study of Government decision-making, analysis of policies themselves, various inputs that have created them, and the inputs needed to produce alternative policies" (McKinney \& Howard, 1998).

The Public Administration is an organizational structure that represents the basis for decision-making and implementation of decisions, rules according to which public services are carried out." Public Administration is one of the main segments through which the relations between the State, Civil Society and the Private sector are realized. In this regard, supporting innovations in Public Administration enables the realization of development objectives, in particular the economic advantages, poverty reduction, harmony and institutional stability (Stavileci, 2005). 


\section{Intention}

Such objectives require the participation of the Company in defining, directing, monitoring and evaluating intergovernmental management and establishing direct consultations, strengthening coordination mechanisms to assess the quality of public management, efficiency and results, and establishing close relationships between Civil Employees, in order to promote a professional civil service through various fields of specialization.

\section{General Aspects Related to Development of Public Administration in Kosovo}

The Public Administration in Kosovo is relatively new since the post-conflict period beginning in 1999 when the building of a new system and a new social order began, which preceded a new system of Public Administration in Kosovo. Although it is known that its functioning was early, especially after the Second World War, the Public Administration in Kosovo did not maintain the continuity of action after the establishment of the Civil and Military Mission (UNMIK and KFOR). The Resolution of the United Nations (UN) Security Council 1244 also laid the foundations for the functioning of Public Administration in Kosovo. The Resolution designated UNMIK as responsible for the functioning of the Public Administration. By the Resolution, the International Civil Mission was entrusted with tasks and responsibilities in the political and administrative area at three levels: a) the Kosovo Interim Administration; b) the establishment of Institutions of Democratic Self-Government, their supervision including the electoral process; and c) transferring responsibilities to Kosovo Institutions. The resolution defined the stages of gradual transfer of competencies in the Administration of the Presidential Administration and other areas that passed to the success of the creation of Kosovo.

The Interim Joint Administrative Structures (IJAS) as Interim Organs established in May 2000 were replaced by the Provisional Institutions of Self-Government (PISG) following general elections for the new Institutions. During the first five years of the post-conflict period in Kosovo, the construction of Public Administration went through three main phases: the establishment of the United Nations (UN) Interim Administration, the establishment of the Provisional Institutions of Self-Government (PISG) and the launch of implementation plan "Standards for Kosovo".

The Constitutional Framework for Provisional Self-Government in Kosovo, adopted in May 2001 by the Special Representative of the Secretary-General (SRSG), sets out the role of the PISG and the sharing of their responsibilities with UNMIK (Law in Force in Kosovo, Regulation no.2000 / 45 on Self-Government of Kosovo Municipalities).

In this direction, the establishment of Kosovo Institutions with three Main Pillars: the Legislature, the Executive and the Judiciary played an important role, although some competencies still remain reserved for UNMIK. The PISG strongly supported the idea that Kosovo's future was linked to Europe, therefore they are committed to ensure that all legislation, especially in the field of Education, Economy and Health, is in line with European Union Standards. This process of capacity building in Public Administration required great political commitment, patience, careful planning and long-term vision as well as effective implementation of EU rules.

The main strength of the PISG reflected the will of Kosovars to establish a functioning Administration, where as a temporary stabilizing factor was the International presence and the great technical assistance that was granted to Kosovo with various projects, in order to create a functioning administration, responsible and reform-oriented. The adoption of European values and norms in every system of administration has promoted the coherent development of Institutions. The Legal, Institutional and Administrative Framework for Civil Service management was set up, both at the local and central level.

\section{Strategies for Public Administration Reform}

Given the inefficiency of Public Administration in providing services to citizens, institutions, businesses and Civil Society and the high cost of this administration, The Government of Kosovo with Decision No. 4/172 dated 25.10.2005, has approved the initiative of the Ministry of Public Services (MPS) for drafting the "Strategy for Public Administration Reform in Kosovo" (PAR). This Ministry was entrusted by the Government with the management and implementation of this project, the formation and supervision of the work of the Inter-Ministerial Group and the Group of Experts for Public Administration Reform in macroeconomical Kosovo regarding the trends of the main economic and financial indicators; Regulation and Institutional arrangements for macroeconomic policy coordination (Annual work report of the Ministry of Public Services for 2006).

As a result of this, many recommendations have been made which can be used by the Government of Kosovo in general or by individual Institutions within the administration to improve structure and functionality. However, these recommendations represent only the first step in the Public Administration reform process. The FRIDOM project has also supported the Ministry of Public Administration in preparing a new Legal Framework for Public Administration. The FRIDOM functional review project 
was completed at the end of June 2010 and the Kosovo Government is continuing to implement the set recommendations. As a continuation of this progress, Government Email services, file management services and posting of Government Institutions websites have been provided to Government staff. Several databases have been created, which serve the staff of special Ministries such as: Payment system, Budget system, Register of cadastral transactions, register of vehicles and driver's licenses, electronic voting in the Assembly of Kosovo, KosGIRO that enables payment of various invoices through the internet, etc.

The Kosovo Government in January 2010 approved the "Strategic Development Plan 2009-2013" for the Ministry of Public Administration. This plan includes the reforms proposed by the FRIDOM project approved by the Government in 2008 and aimed at reforming the Public Administration at the central level. (FRIDOM reports-Ministry of Public Administration, Kosovo).

\section{Literature Review}

From the basic documents of the reform of the Public Administration in Kosovo it can be concluded that the Public Administration reform in Kosovo is of the type of administration modernization. This way of Public Administration reform is typical for countries in transition (unlike the models of "revolutionization of administration" and "new public management", models characteristic of different countries of the world, especially for developed countries) (Batalli, 2012).

In all Central and Local Institutions, to be obliged (recommended) to hold training on ethics in Administration as a measure to prevent abuse of office by officials of Central Administration and Local Administration. To form disciplinary Commissions in each Institution where they have not been formed, while where they are to be functionalized and to be more effective, the Members of the Commission to be nominated distinguished officials who have been evaluated with high etiquette and principle in work.

The interface for running the show is aimed at organizing and holding a political party, you can publish its assessment for communities, if you want to become a democrat in Kosovo. Also, (communities) have the opportunity to further manage their service, where they can look at communities, how to provide Representatives and integrate into the Government of Kosovo, participate in the central ones. Whereas, in those locals this number has been exceeded, show this opportunity for more than the Albanian community (Shala, 2015).
While Kosovo Law provides an adequate normative framework governing the enforcement of detention during criminal proceedings and is largely in line with applicable International Standards, various problems regarding the enforcement of detention in practice still remain. Detention requests filed by Prosecutors and Pre-trial Detention decisions approved by PreTrial Judges often contain insufficient reasoning (Abazi, 2018).

Preserving and respecting fundamental human rights and freedoms is and remains the main priority of modern societies, given the fact that they have been achieved and embedded in the consciousness of Western societies at very high human and historical costs. As a joke world history presents us with new challenges demanding the need to find a new balance between respect (Gashi, 2015).

\section{Challenges Towards the Process of Public Administration Reform in Kosovo}

Kosovo has gone towards a difficult but very important process in the area of functioning of Public Administration. Public Administration reforms at the level required in Kosovo, required time, demand and perseverance, but also a clear vision, precise direction, leadership, conviction and stability as well as sufficient resources (Stavileci, Sokoli \& Batalli, 2010). This process required a series of administrative actions, rules, drafting of a strategic plan, creation of a technologically designed infrastructure as well as identification of instruments, to achieve certain objectives. Due to the conflict in Kosovo at the end of 1999, the Public Administration faced many problems. The common feature of the public sector governance and management system was the requirement to transform the previous model of administration into a modern model of administration. Initially, there was a lack of efficient Institutional capacity to formulate, coordinate and evaluate strategic civil service policies in Kosovo.

Therefore, the professionalism of civil servants was considered a priority in public administration reforms. The concept of transparency, accountability and efficiency in public management needed to be better understood by Managers, Staff, Municipalities and Agencies. The implementation of Information Technology (IT) in Kosovo started with a delay compared to other countries in the region, due to the situation in Kosovo. Governance and capacity management in the Public sector in post-war Kosovo had to be viewed from a slightly broader perspective. The goals, priorities and achievement objectives of an organization could not be set outside the local and central policy agenda as well as the macroeconomic framework. 
The three levels of capacity building, focused on creating the environment, building institutions and developing human resources, assessed the weaknesses and strengths of the Public Administration in Kosovo. A more comprehensive reform process was hampered by the fact that the Administration was divided into "reserved" and "transferred" powers, that is, powers that were transferred to the PISG and the functions that remained reserved for the UNMIK Administration.

\section{Conclusions}

From the basic documents of the Public Administration reform in Kosovo it can be concluded that the Public Administration reform in Kosovo is of the type modernizing the administration. This way of public administration reform is typical for countries in transition (unlike the models of "revolutionization of administration" and "new public management", models that are characteristic for different countries of the world, especially for developed countries). The type of modernizing the administration is understood more as a form of reform in terms of new structuring of the administration in line with systemic changes or as a way of increasing the efficiency and effectiveness of the work of administration. According to this type of reform, there is no radical change in the role and function of the administration as it remains a Public Sector that is managed according to public sector rules. The essence of Public Administration reform, according to the type of modernization, lies in the changes in the work of the administration in relation to the citizens, the efficiency and effectiveness of the administration, as well as the reduction of administrative costs.

The reform of Public Administration in Kosovo as a change and development is influenced by many factors related to the administration itself and its development, as well as the general development of the state. Public Administration reforms in Kosovo have brought important changes, because they are part of comprehensive developments. A functioning and transparent public administration is also an important contributor to state legitimacy and credibility. Today in Kosovo, all central institutions have access to the Internet, which is provided through the IT System Center managed by the Ministry of Public Administration.

Internet access by these institutions is based on their needs and in accordance with applicable administrative instructions. However, the organization and structure of the administration are still problems faced by the public administration at the central and local levels. Codification of administrative procedures is one of the most powerful and effective mechanisms for Public Administration reform in Kosovo and the decision-making process. Appropriate advancements in the area of governance initiatives and processes depend heavily on the role of government in ensuring an appropriate legal framework.

\section{References}

1. Denhard R. and Janet P. (2009). Administration: An Action Orientation. 6th Ed. Thomson Wadsworth, Belmont CA.

2. Dwigh W. (1972). Developments in Public Administration: The Annals of the American Academy of Political and Social Science.

3. Donald K. and James F. (2009). The Politics of the Administrative Process. Washington D.C.

4. Mirlinda B. (2011). Impact of Public Administration: Innovations on Enhancing the Citizens' Expectations, International Journal of e- Reforma e administratës publike në Kosovë Thesis, Vol.2.

5. Mirlinda B. (2008). Osnovne crte kompjuterizovane javne uprave, Hrvatska Javna Uprava, Journal no. 2.

6. Mirlinda B. (2011). Simplification of public administration through use of ICT and other tools, European Journal of ePractice. Vol.12.

7. Mark. B. (2004). Zhvillimi i demokracisë së pushtetit vendor në Kosovë, për IDEA-nNdërkombëtare. Available: https://www.researchgate.net/publication/315337450_Refo $\underline{\mathrm{rm} \text { of Public Administration in Kosovo }}$ 